applying class theory, historians can explain some of the reasons why individuals could belong to two distinct social identities, Roman and African. Class theory also helps to explain why some indigenous A fricans could and did construct for themselves a Roman identity and others did not.

\title{
4.3 Ancient African Christians and Class Identity
}

Scholarly debate regarding the issue of class in early Christianity is by no means new. Peter Brown summarizes the exasperation of many recent historians when he says, "There is little room for the myth ...which presents the advance of Christianity as due to the spread of a religion of mercy and equality among the underprivileged. Christianity was by no means the religion only of slaves and of simple folk. Rather, the third century was an age of surprising Christians, of whom the emperor Constantine was only the last." ${ }^{, 49}$ Recent scholarship has called into question the understanding that early Christians were uneducated oppressed masses. Stark claims that the "new consensus" among historians is that Christianity was based in the middle and upper classes, and he contributes to the discussion by comparing early Christian communities to demographic studies of cults and sects in the U.S. ${ }^{50}$ Stark recognizes the objection that his approach is valid only in contemporary Western society, and he responds that such an objection (1) ignores the principles recognized by any "competent social scientist," and (2) ignores the evidence laid out in his entire book. ${ }^{51}$ Whether or not one agrees with the applicability of Stark's "scientific" methodology in regards to ancient North Africa, it establishes a theory of class with which to compare the data available to the historian. ${ }^{52}$

In the early period of African Christian history, the records suggest that both upper and lower class members of society existed within Christian communities. The Scillitan martyrs, although beheaded as if Roman citizens, are generally recognized as lower class members of society. ${ }^{53}$ In the Passio sanctarum

49 The Rise of Western Christendom: Triumph and Diversity, A.D. 200-1000, 2nd ed. (Oxford: Blackwell Publishing, 2003), 63-4.

50 The Rise, 31. Stark reflects earlier studies of Robin Scroggs, "The Sociological Interpretation of the New Testament: The Present State of Research," NTS 26 (1980): 164-78; and Robert M. Grant, Early Christianity and Society: Seven Studies, (San Francisco: Harper and Row, 1977), 11.

51 Ibid, 45.

52 The supposed "new consensus" has been sharply criticized. For Palestinian Christians of the 30s and 40s, see John Dominic Crossan, The Birth of Christianity: Discovering What Happened in the Years Immediately After the Execution of Jesus, (New York: HarperSanFranscisco, 1998), who uses anthropology of class, locating early Christians among the poor. For Pauline communities, see Meggitt, Paul, who engages anthropological theories, but prefers theories from the discipline of economics in helping to locate early Christians within the "general experience of deprivation and subsistence" (75).

Musurillo, The Acts, xxiii; Barnes, Tertullian, 63. 
Perpetuae et Felicitatis, the narrator emphasizes Perpetua's social status, as if nobles among Christians were rare. ${ }^{54}$

Whether or not many Christians in Africa were of the noble classes, outsiders like Celsus perceived Christians only as uneducated working class peasants, according to Origen who claims,

Celsus quotes what is entirely contrary to Jesus' teaching, and is maintained only by a few people who are supposed to be Christians, not, as he thinks, by the more intelligent, but by the most ignorant. He says: Their injunctions are like this. "Let no one educated, no one wise, no one sensible draw near. For these abilities are thought by us to be evils. But as for anyone ignorant, anyone stupid, anyone educated, anyone who is a child, let him come boldly." By the fact that they themselves admit that these people are worthy of their God, who they show that they want and are able to convince only the foolish, dishonourable and stupid, and only slaves, women, and little children. ${ }^{5 s}$

...wool-workers, cobblers, laundry-workers, and the most illiterate and bucolic yokels, who would not dare to say anything at all in front of their elders and more intelligent masters. ...And if just as they are speaking they see one of the school-teachers coming, or some intelligent person, or even the father himself, the more cautious of them flee in all directions. ${ }^{56}$

In response to Celsus' claim Origen does not deny the lower status class identity of most Christians, but compares this to the demographics of society in general: "However, it was inevitable that in the great number of people overcome by the work because there are many more vulgar and illiterate people than those who have been trained in rational thinking, the former class should far outnumber the

$54 \quad P S P F$ 2.1-2: "A number of young catechumens were arrested, Revocatus and his fellow slave Felicitas, Saturninus and Secundulus, and with them Vibia Perpetua, a newly married woman of good family and upbringing." [Apprehensi sunt adolescentes catechumeni, Reuocatus et Felicitas, conserua eius, Saturninus et Secundulus. Inter hos et Vibia Perpetua, honeste nata, liberaliter instituta, matronaliter nupta.] cf. 6.1-2, where Perpetua seems to have been afforded some special distinction by the officials.

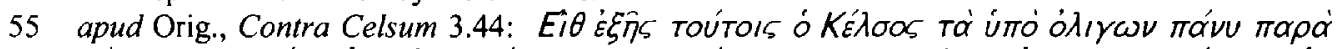

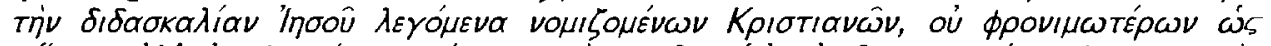

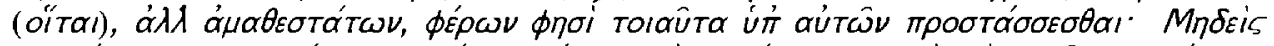

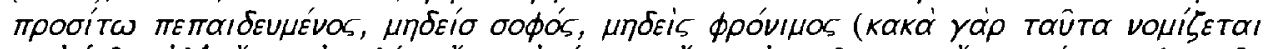

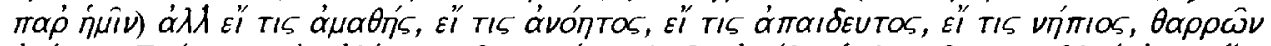

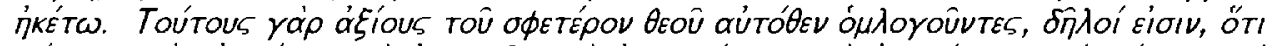

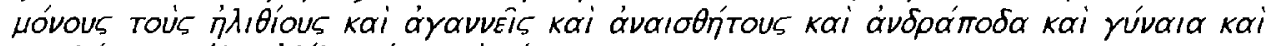

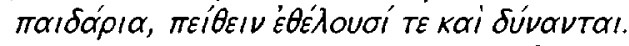

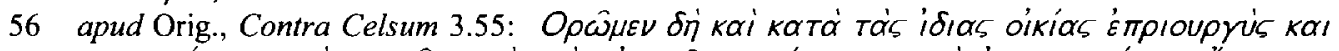

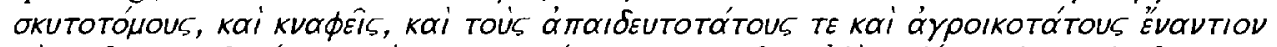

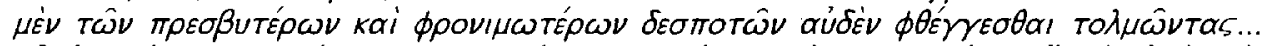

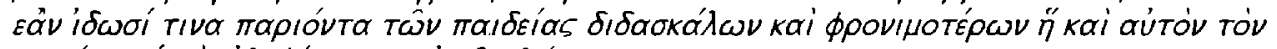

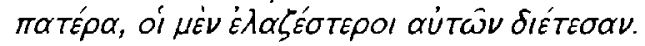


more intelligent. But Celsus did not want to recognize this fact." ${ }^{157}$ While Origen does not give direct evidence for Africa Proconsularis, he does provide insight into the class makeup of Christianity contemporary to Tertullian and very similar in context. ${ }^{58}$ Fronto, moreover, alleged that Christians "collected from the lowest possible dregs of society the more ignorant fools together with gullible women., ${ }^{59}$ Because Fronto spent much time in Rome, his account may not relate directly to North Africa, but it does align with other sources from neighboring regions and time periods, making its application to North Africa plausible. ${ }^{60}$

\subsection{Tertullian and Class Identity}

To which class of Roman society was Tertullian born? His skill as a trained orator and his education indicated in his writings seem sufficient to surmise that Tertullian came from or rose to a high level of status or class. Perhaps a more pertinent question, however, and one that can be explored in Tertullian's own works, is "In which class did Tertullian place himself?", or "How did Tertullian construct and depict his own class identity?" Despite the propaganda from nonChristian Romans and new elites, many Christians came from noble ranks in North Africa. The vast majority of Christians, however, were plebs with little or no claim to status as defined by Roman social norms. In order to investigate with which end of the social spectrum Tertullian expressed solidarity the following section will analyze his works De cultu feminarum 1 and 2.

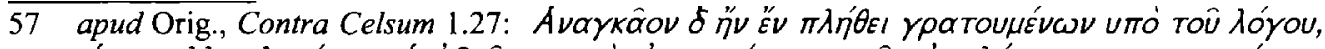

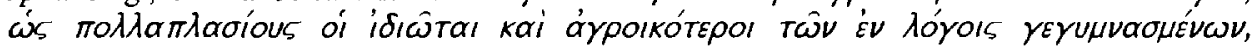

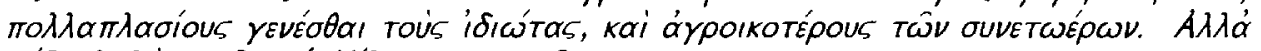

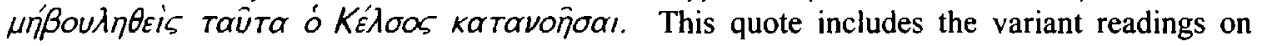
which Chadwick's translation relies.

58 cf. Pliny's declaration of surprise at upper class Christians, Epistula 10.96.4: “...I am convinced that their stubbornness and unshakable obstinacy ought not to go unpunished. There have been others similarly fanatical who are Roman citizens" [Neque enim dubitatam, qualecumque esset quod daterentur, pertinaciam certe et inflexibilem obstinationem debere puniri. Fuerunt alii similis amentiae, quos, quia cives Romani erant, adnotavi in urbem remittendos.] See Braun, "Aux Origines," 192, who contrasts the low class makeup of the Scillitan Christians with the community of Tertullian.

59 apud Minucius Felix, Octauius 8: de ultima faece collectis imperitioribus et mulieribus credulis.

60 For class, esp. lower classes, in Cyprian's flock, see R.H. Weaver, "Wealth and Poverty in the Early Church," Interpretation 41 no 4 (O 1997): 368-381; Frend, "The Early Christian Church in Carthage" in Excavations at Carthage 1976, vol. 3, ed. J.H. Humphrey, (The University of Michigan/Ann Arbor Press, 1977), 33. Similarly, with the Donatists, see Shaw, "African Christianity," 29-30. 